\section{ECONOMICS}

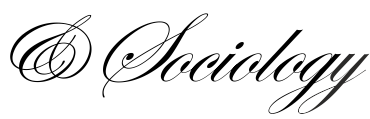

Abbas, A., Sunguh, K. K., Arrona-Palacios, A., \& Hosseini, S. (2021). Can we have trust in host government? Self-esteem, work attitudes and prejudice of lowstatus expatriates living in China. Economics and Sociology, 14(3), 11-31. doi:10.14254/2071-789X.2021/14-3/1

\title{
CAN WE HAVE TRUST IN HOST GOVERNMENT? SELF-ESTEEM, WORK ATTITUDES AND PREJUDICE OF LOW-STATUS EXPATRIATES LIVING IN CHINA
}

\author{
Asad Abbas \\ Writing Lab, Institute for the \\ Future of Education, \\ Tecnologico de Monterrey, \\ Monterrey, Mexico \\ E-mail: asad.abbas@,tec.mx
}

\section{Kenneth Khavwandiza}

Sunguh

School of Management, University

of Science and Technology of China,

Hefei, P.R. China

E-mail:sungub@,mail.ustc.edu.cn

\section{Arturo Arrona-Palacios \\ Writing Lab, Institute for the \\ Future of Education, \\ Tecnologico de Monterrey, \\ Monterrey, Mexico \\ E-mail: arturoarrona@,tec.mx}

\section{Samira Hosseini \\ Writing Lab, Institute for the \\ Future of Education, \\ Tecnologico de Monterrey, \\ Monterrey, Mexico \\ E-mail: samira.hosseini@,tec.mx}

Received: March, 2021

1st Revision: June, 2021

Accepted: September, 2021

DOI: $10.14254 / 2071-$

789X.2021/14-3/1

JEL Classification: F22, F66, G38, J00, J6, J7, M54
ABSTRACT. The paper aims to investigate whether trust in a host government can mitigate the negative effects caused by the social complexities facing low-status expatriates (LSEs) living in China. It models trust in host government as a mediator in the relationship between expatriates' perception of status-based prejudice and their work attitudes; it further outlines the role of self-esteem in this relationship. The study seeks to expand knowledge in the domain of expatriate management by explaining the prejudicial behavior of host country towards low-status expatriates. Structural equation modelling was used to analyze responses from LSEs in China. The results provide the evidence that perceived discrimination negatively affects expatriates' work attitudes and suggest that trust in the host government can mediate such effects. Self-esteem is found to be a significant moderator in the relationship. With this, the study empirically affirms social categorization theory, showing it to be a powerful lens through which LSE adaptability can be the behavior of host nationals towards low-status expatriates and can be further developed with regard to the adaptability of low-status expatriates.
Keywords: adaptability, expatriates; educational innovation; selfesteem, trust in host government, social categorization theory, China. 


\section{Introduction}

The increased presence of labeling as well as stereotyping based on the race, country of origin and gender of expatriates results in a notable difference in assignment success between local and foreign employees, hindering the growth of global mobility and expatriation (Varma, Toh, \& Budhwar, 2006). This elusive aspect of human nature is often mentioned as one of the major obstacles to easy movement. It is claimed to increase uneasiness, reduce international job commitment and lead to psychological challenges (Bonache, Langinier \& Zárraga-Oberty, 2016), all of which hinder building a trustworthy workplace atmosphere and adaptability in the workplace. However, conditions can be improved with special training and by selecting expatriates with previous international job experience and personality traits that enable them to cope with the challenges related to expatriation (Minter, 2008). Such selection and training are based around cultural adaptation as well as communication and lifestyle differences (Hutchings, 2003). This is done in the hope that once the expatriates are posted, they will build confidence and develop trustworthy and sociable interactions with host nationals. Studies have found these relationships to be essential for the adaptability and success of expatriates in carrying out their assignments comfortably. Though these positive effects are widely accepted, neither the stereotyping and categorization of expatriates by locals into categories of high status (i.e. more connected to the success, ability, and willingness to create organizational change in the community) and low status (i.e. lack of social capital, fewer social ties, and discrimination by race and gender) have been completely understood, nor their impact on expatriates' work attitudes (Guttormsen \& Francesco, 2019; McNylty \& Brester, 2017). We chose China for this study, due to the government's flexible foreign policy and the world's second leading economy (Abbas et al. 2018) with the aim to attract foreigners to invest in terms of Foreign Direct Investment (FDI) and also to create job opportunities for both locals and foreigners. Recent initiative of the Chinese government, Belt Road Initiative (BRI), with the concept of regions connectivity through land and sea also attracts nations from developing regions (Jannesari \& Sullivan, 2021) to collaborate and share resources for development. This set of initiatives promotes interaction between people, business communities, and governments to share culture, education and business through mutual agreements. The latest Chinese government's initiative provided opportunities to low-status expatriate to work in China.

In this paper, social categorization theory is used as the theoretical lens, through which the effects of stereotyping and prejudice on expatriates' success in international assignments is understood. To account for various aspects of stereotyping, preceding studies suggest the conceptual use of perceived prejudice from the expatriate's perspective (Bonache et al., 2016). Its influence on expatriate's work attitudes, namely job commitment and turnover intention, is investigated in a research model using trust in the host government as the main mediating variable. Furthermore, expatriate's self-esteem is used as a moderator of the relationship between trust and work attitude. In total, this research attempts to offer potential contributions. Firstly, it uses the perceived prejudice construct in a social categorization context, providing empirical evidence that the theory is an effective framework for understanding low-status expatriates. This fulfills a recent call for studies on the question of which theory provides a better sense of this group of expatriates (i.e., low-status expatriates). In doing so, it sheds light on the critical value that identity and status have on the adaptability of expatriates; it further highlights the role that the trust in the host government has in helping low-status expatriates develop work attitudes essential for their success. Secondly, if offers a full understanding of the crucial role local nationals' attitudes play in expatriate's development and what impact expatriate's status has. Finally, it reveals the significance of studying the effects of negative social aspects on the adaptability of expatriates, a highly important area that has received relatively lesser attention in the recent times. 
The remaining sections of this article are structured as follows. The study starts with the theoretical development by conceptualizing the categorization of expatriates by local nationals through the social categorization theory lens. Next, the research model and proposed hypotheses are presented, followed by a description of the research methodology. The study then presents the empirical results and a subsequent discussion of the main findings and their implications. The conclusion, limitations of this study and possible directions for future research are presented in the final section.

\section{Theoretical framework}

Expatriate adaptability and successful completion of international assignments are crucial themes in global mobility studies. The literature distinguishes between high-status expatriates and low-status expatriates (Fechter \& Walsh, 2010; Toh \& DeNisi, 2007). The latter include those expatriates originating from countries perceived to be of low status, mostly developing countries. They are individuals temporarily working as foreign nationals whose status in the host country is perceived to have an inferior rank compared to locals or other (higher status) expatriates. In this section, we will elaborate first on the main arguments for why identity and status are important for the adaptability and success of expatriates. Secondly, we will discuss the theoretical and existing empirical grounds for perceived government support towards successful expatriation. We will finally analyze the implications of this line of reasoning for low-status expatriates and how their self-esteem and trust in the host government to protect them could be critical for their success.

\subsection{Social categorization by identity and status}

The relevance of status and identity to social interactions goes back to classical texts in sociology (Ar, 2021). In their seminal work, Dovidio et al., (1998) elaborate on the significance of identity and status to social relations including the formation of social groups or classes, the reception of recognition and support, and the practice of stereotyping, either positive or negative. In recent times, there is still an emerging debate - fueled mainly by the mass movement of people from developing countries into the developed world - on the reasons why status and identity matter for the adjustment of individuals in foreign lands (Rosenbusch \& Cseh, 2012). The discussion suggests that possession of a higher status is favorable in significant ways. Particularly, individuals originating from countries ranked favorably on economic and political scales are given the status of investors, while individuals coming from low-ranked countries are deemed to be immigrants.

Social categorization theory (SCT) provides an essential theoretical basis for understanding stereotyping based on age, gender and race (Toh \& DeNisi, 2007). A study by Varma, Budhwar, and Pichler (2011) argues that people are categorized into social groups for several reasons, including unavailability of sufficient knowledge and malicious prejudice. This leads to the formation of social groups, some of which are regarded as high status and others of which are perceived to be low status. Membership in a group regarded to be of high status is thought to contribute positively one's social identity. Moreover, members of groups deemed to be of low status are perceived in a negative manner, which in turn negatively affects their selfconcept (Bonache et al., 2016). Since the self is defined by membership in such groups, a loss of membership or a change in the meaning of a group identification is expected to influence the individual self. In our case, the adaptability and cultural adjustment of expatriates - factors that research has found to be essential for their success - are influenced by such group-membership changes success (Terry et al., 2006). 
Previous research using social categorization theory has linked variations in group status to different outcomes, at both group and individual member levels. For instance, low-statusgroup members have been found to possess lower self-esteem as compared to high-status-group members, and therefore they tend to display more uneasiness during intergroup interaction. Accordingly, at the individual level, a study by Ellemers et al., (1999) suggests that members in low-status groups experience more psychological difficulties than their counterparts. This leads them to seek to dissociate themselves from the in-group more than high-status-group members. Furthermore, research has provided evidence of benefits attached to being a member of a group perceived as high class. For instance, a study by Cuddy et al., (2005) posited that member in this group are perceived to be more competent: competence was attributed based on the wealth and status of individuals' respective countries. Consequently, expatriates from developed countries would be favorably picked over their counterparts from developing countries during job allocations. For example, manual jobs in the Middle East are mostly allocated to expatriates from African and South Asian countries, while management jobs are assigned to expatriates from Western developed countries.

In addition to job categorization, it has been shown that local nationals prefer to be associated with high-status expatriates, since this association can give them self-esteem and confidence. Research by Haak-Saheem et al., (2017) demonstrates that expatriates perceive their racial identities and ethnicities as having the greatest impact on the response and support they receive when interacting with host nationals. Due to the willingness of the host nationals to associate, relate and interact with high-status expatriates, these expatriates have an advantage over their peers in low-status groups. The support they receive helps with their cultural adaptation to the foreign work environment, and thus they are expected to have greater job commitment and lower turnover intention, which in turn result in the successful completion of assignments (Varma et al., 2011). Based on the above discussion, expatriates perceived to be of higher status will be expected to be more productive and more adaptive than those belonging to low-status groups.

\subsection{Emotional stability and expatriate success}

It has been established in the above literature that status and identity have a significant role to play in regard to the adaptability and cultural adjustment of expatriates. This does not mean that status and identity are necessarily the main factors in their success. Research has shown that adaptation and adjustment of expatriates to fit their job demands is a very tedious and complex process. A study by Shaffer and Harrison (1998) broke down this process and suggested that favorable results could be achieved via three levels: (a) by ensuring adjustment to the general environment in the host country, (b) by ensuring psychological adjustment to different work standards and expectations, and (c) by ensuring the adjustment to host-nationalinteraction that is essential for communication and cultural adaptation (Pinnington, 2011). According to work by Aycan (1997), adjustment can be achieved through the interaction of individual factors, organizational factors and environmental factors. Individual factors relate to the personal traits and skills that allow an individual to adjust more easily and faster to a new environment: these factors include self-esteem, interpersonal skills and personal motivation. Organizational factors include activities carried out by organizations to assist expatriates, such as providing pre-training in language and communication skills. Finally, environmental factors relate to macro issues: political and economic stability in the host country and the degree of cultural difference.

Once these factors have been addressed, a level of adjustment is expected among expatriates. Feldman and Tompson (1993) posit that there are four variables which would indicate the level of adjustment to new work: work satisfaction, turnover intention, 
psychological wellbeing, and quality and quantity of activity expected by management. Satisfaction and turnover intention are mostly attitudinal variables linked to the emotional state of the expatriates. They denote a general feeling of safety and satisfaction. Safety of expatriates away from home is of particular concern for current research. Instances of xenophobic attacks in South Africa against workers from other developing countries - mainly African countries brought attention to the debate on the role of the host government in ensuring the security and safety of expatriates. For an expatriate to register positive performance, their safety should be guaranteed for the sake of their psychological wellbeing. As suggested by Caligiuri (2000), just as technical skills are an essential requirement for the success of expatriates' assignments, so are their social and perceptual abilities, their individual personality, their intercultural intelligence and an enabling, adaptable and secure environment.

\subsection{Implications for low-status expatriates}

The discussion above suggests that the adjustment and adaptability of expatriates is essential for their success. Furthermore, it establishes that various factors do assist in this adjustment, including individual factors such as possession of favorable social status and personal attributes like self-esteem and personal motivation. The literature also suggests that feelings of psychological wellbeing and safety help expatriates to develop positive commitments to their jobs and thus provide grounds for a successful international career (Ipek \& Paulus, 2021). Political stability and a just host government - such that expatriates expect the government to act in a fair manner to protect them against harm and that the law will prevail - contribute to the development of these feelings (Faeth \& Kittler, 2017). It is therefore apparent that low-status expatriates can face a triple disadvantage of (1) low support from locals as compared to high-status expatriates, (2) psychological distress due to direct or indirect prejudice and (3) a sense of insecurity and fear of harm. By maintaining the theoretical proposition that status, identity and sense of security are essential facets for a successful expatriate experience, the important question for the low-status expatriates is therefore whether they can compensate for the lack of status and feelings of insecurity by developing relations with external actors that would provide social capital and help expatriates cultivate useful individual capabilities. Such relationships could provide necessary social capital by championing the expatriates' security, thus providing them with peace of mind. They could also assist the expatriates in the adjustment and adaptability processes, fostering individual capabilities to make the expatriates competitive and ensure a successful expatriation (Caligiuri, 2000).

While there are various ways of developing worthwhile relations, including but not limited to forming work unions, joining international workers organizations, etc. (Mäkelä, 2007), developing trust in the host government plays a major role in persuading expatriates to maintain a positive attitude towards the new working environment (Osland \& Björkman, 1998).

Apart from instilling confidence and the perception of safety and security, trust in the host government provides expatriates with a much-needed platform to address other social challenges. For example, policies and laws could be enacted to curb segregation and unfair treatment, assisting in the adjustment process (Florkowski \& Fogel, 1999; Jureidini, 2005). This can provide assurances to potential expatriates who might be willing to travel in search of job opportunities but are afraid to do so due to worries about prejudice. McPhail, McNulty, and Hutchings (2016) assert that the cross-cultural adjustment of expatriates is a complex process that is always socially construed. Conflicts between identity and career choices arise that might be detrimental to the psychological wellbeing of the expatriates and lead to loneliness, depression and feelings of isolation. This implies that low-status expatriates can thrive and be successful in their respective fields as long as they learn how to counter the negative effects attached to their identity and status by creating a balance between their career expectations and 
the realistic encounters, they have in their host environment. It is clear that low-status expatriates are at a disadvantage compared to their high-status colleagues; however, social capital, including host government support, combined with cognitions like personal motivation and self-esteem can result in the desired adjustment essential for their success.

It would be expected, therefore, that low-status expatriates rely most on their selfcognitions and the trust in government to adjust and hence be productive. Research on the role of host governments in the adjustment and adaptability of expatriates is scarce. Previous studies have focused mostly on the roles of the expatriates' families, organizational support and individual characteristics in expatriation success (Caligiuri, 2000). Varma et al. (2011) investigated the role of host nationals using self-efficacy and motivation theories, and developed a research model that outlined their role in the success of expatiates. Their study underpinned the crucial role played by host nationals in the adjustment process, and it found that a lack of support from host nationals may impede expatriates' performance. Florkowski and Fogel (1999) found that host nationals are not always interested in offering their support to expatriates and at times treat expatriates as outsiders, withholding relevant information. In line with social categorization theory assumptions, host nationals categorize expatriates into groups, whereby they show willingness to provide crucial information to those expatriates perceived to be in-group while withholding the same information from out-group members. Due to a lack of knowledge of individual capabilities and skills, they oftentimes use demographic features such as race and ethnicity in deciding which group to allocate the expatriates. Expatriates perceived to be of low status end up in the out-group while those of high status are considered to be ingroup, and hence the support from host nationals is always lower to the former than to the latter. Despite these challenges, many success stories are told by low-status expatriates who chose to remain committed to their assignments, overcoming hardships to be successful. We intend to therefore provide evidence supporting the notion that the low-status compensate for reduced support by using self-cognitions and trust in government. More empirical research is needed to demonstrate what role host governments play and this study aims to provide that by specifically investigating how trust in host government might mitigate the effects of prejudice on expatriate commitment and turnover intentions.

This study intends to integrate social categorization and social capital theories in explaining the choice of low-status expatriates to remain committed to their international assignments despite the negative connotations attached to their status and identity. Social capital theory rests on the premise that people often initiate and maintain connections that can assist them (Borgatti et al., 1998). This is done by establishing, developing and retaining relationships whose main purpose is to generate benefits, tangible or intangible and long- or short-term. A study by Ko and Hur (2014) asserted that gains from trusted relationships can be social, emotional, psychological or economical. We pursue this line of thought - derivation of intangible benefits - by postulating that low-status expatriates can have trust that the host government will provide them with desired security and intervene fairly in the unlikely event that they are faced with harmful or unpleasant experiences. They may also expect that the host government does not condone any type of segregation by governmental institutions or host nationals. These assurances can allow the expatriates to have peace of mind, and they are therefore able to concentrate on their jobs. On the flipside, when this trust is broken, it can lead to dissatisfaction and a feeling of betrayal that might be detrimental to expatriates' performance. Their safety might also be endangered, forcing them to terminate their assignments before completion. The illustration in Figure 1 presents the research model and indicates the variables used in this study. 


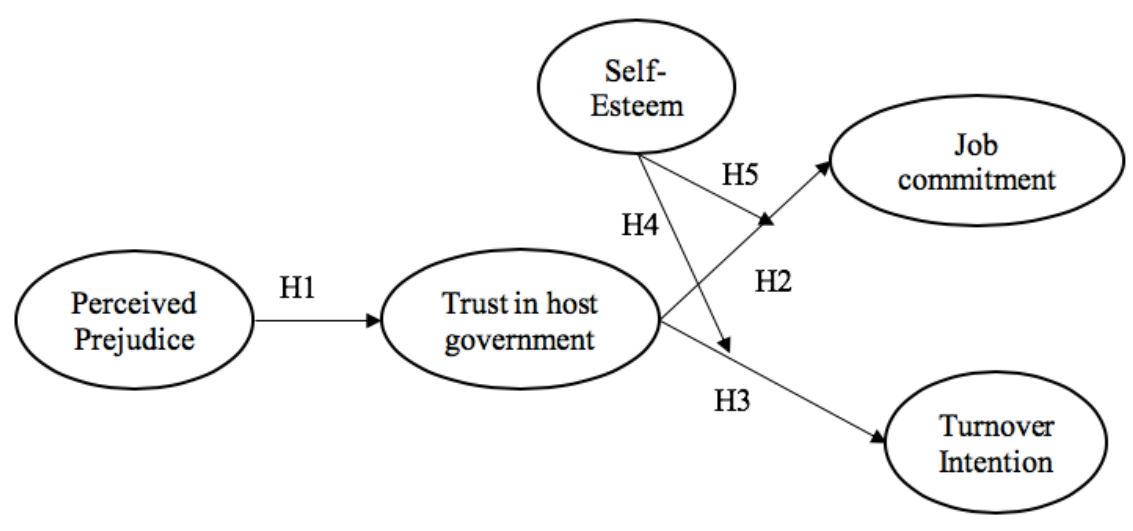

Figure 1. Research model

Source: own

\subsection{Hypotheses}

The research model for this study is presented in Figure 1. Host governments can assist expatriates in overcoming the negative impact race- and nationality-based prejudice has on developing healthy and favorable work environments (Faeth \& Kittler, 2017). Trust in the host government by low-status expatriates living in China should assist in mitigating the negative effects from perceived prejudice. The model expects that perceived prejudice has a negative influence on job satisfaction and a positive influence on turnover intention, but these effects are expected to be reduced by trust in the host government.

\subsubsection{Perceived prejudice and trust}

Expatriate adjustment and adaptability to a host country are socially construed phenomenon. The process involves interacting with people from different ethnic, cultural and linguistic backgrounds. These interactions are part of a learning process that allows expatriates to share the challenges they face, learn new basic interpersonal skills in terms of new language and cultural values (Mäkelä, 2007), and develop respectful and meaningful relationships with host nationals who in turn provide them with critical and relevant information success (Varma et al., 2011). When these interactions are strained - for instance, in the case of stereotyping or prejudice due to race, gender, age or status - negative effects on the expatriate's job commitment can occur that might trigger an intention to quit. Presence of perceived prejudice will reduce expatriate-host national interactions, leading to negative emotions such as anger, depression, a lack of interest in developing relationships and uncertainty with regard to safety. Moreover, previous research has established that prejudice and discrimination are linked to negative job attitudes (Ensher et al., 2001). A study by Madera et al., (2012) found that individuals who perceived discrimination tended to have higher turnover intention and lower job commitment. The perceived prejudice affects not only trust in host nationals and colleagues but also trust in the host nation's government, which provides protection and safety for those within its jurisdiction. In nations where prejudice is perceived to be higher, there have been instances of xenophobic actions against foreigners and the role of the host government has been questioned (Sinwell, 2011). We therefore hypothesize that:

\section{H1: Perceived prejudice will have a negative effect on trust in the host government}




\subsubsection{Trust in the host government and expatriates' commitment}

Job commitment is used in this study to indicate expatriates' level of willingness to stay and work until their assignment is satisfactorily completed. According to Riketta (2002), job commitment is the most influential job attitude in predicting employee performance. For the purposes of this study, we use to indicate low-status expatriates' level of commitment to successfully completing their international assignments. Making a decision to search for employment opportunities in foreign countries requires expatriates to engage emotionally and socially with host nationals who are sometimes unwilling to relate and sometimes violent (Toh \& Srinivas, 2012). Trust in the host government can, therefore, be regarded as a significant antecedent belief that helps expatriates to develop emotional and psychological stability, which in turn leads to job commitment (Florkowski \& Fogel, 1999). The trust assists in reducing the social complexities, insecurities and vulnerabilities that an expatriate feels in a country not their own by allowing them to rule out unwanted yet possible behavior by host nationals. Hence, trust in the host government enables expatriates to ease their risk perceptions and premature repatriation intentions, thereby allowing them to participate in trust-associated behaviors such as providing suggestions on how to improve. They are in the same way enabled to create a friendly and conducive working environment, allowing them to stay committed to their assignments. Previous studies have established that countries perceived to be safe, friendly and hospitable to foreign nationals are preferred as destination countries to highly skilled expatriates (de Eccher \& Duarte, 2018). We therefore hypothesize that:

H2: Trust in the host government will increase job commitment and reduce turnover intention.

\subsubsection{Trust in the host government and turnover intention}

Turnover intention in this study is taken to mean the intention of the expatriate to relocate to another country or repatriate to their home country before the completion of their assignment. Lueke and Svyantek (2000) assert that turnover intention is among the main predictors of expatriation failure. Hence, we use intention to quit to represent unsuccessful international expatriation. Recruiting and retention of expatriates are among the main challenges in the field of expatriation. Remaining committed to the job requires expatriates to be able to handle and overcome social constraints associated with international assignments. Trust in the host government can therefore be regarded as importantly assisting expatriates in remaining committed to their jobs (Kim \& Froese, 2012). When expatriates are faced with prejudice, violence or unfriendly assertions, trust in the host government can play an important role in assisting the expatriates to make decisions about whether to quit the assignment or remain committed. The host government can foster this confidence through the provision of trustworthy legal frameworks, the assurance of safety to foreign nationals and the guarantee of protection against potential hostile actions. Doing so can motivate expatriates to engage in trustdeveloping behaviors, such as increased involvement with government agencies, and assist in creating an environment more conducive to attracting and retaining expatriates (de Eccher \& Duarte, 2018). Research has indicated that countries perceived as safer and with friendlier governments experience higher levels of successful expatriate assignment completion. We therefore develop the hypothesis for this relationship:

H3: Trust in the host government will reduce expatriates' turnover intention.

\subsubsection{Expatriate self-esteem}

In their influential article, Luhtanen and Crocker (1992) defined self-esteem as the cognizance of the whole self or specific features of the self: how people feel about their social 
status, ethnicity, physical features, skills, etc. The rationale for using self-esteem as a moderator is that it serves a protective function. When low-status expatriates are faced with perceived prejudice, those with a higher level of self-esteem can fall back on their positive sense of self and remain committed to their international assignments. This line of reasoning is consistent with a study by Harcourt (2013), which found that higher levels of self-esteem protected African American and Hispanic gay and bisexual adolescents from stress related to their sexuality by assisting them in developing coping resources more effectively. Moreover, research has established that self-esteem can play a buffering role in moments of stress. In this regard, we posit that when low-status expatriates are faced with prejudice, while trust in government will assist in developing psychological and emotional peace of mind, expatriates with higher levels of self-esteem will have higher commitment levels and lower turnover intention than those with lower self-esteem levels. We consequently hypothesize that:

H4 and H5: Self-esteem moderates the relationship between trust and expatriates' work attitudes.

\section{Research methodology}

This study investigates the perceived trust in host government and self-esteem to mitigate the negative effects of perceived prejudice on low-status expatriates living in China through the use of social categorization and social capital theories. We conducted two pilot studies with the aim of testing and validating our survey instrument (questionnaire). In quantitative research, range of 10 to 30 samples are considered valid for any pilot study (Johanson \& Brooks, 2010). So, firstly we asked two PhD scholars and one Assistant Professor for verify the questionnaire design check and then circulated the reviewed copy among 20 expatriates working in China to iron out issues of readability and word phrasing. This process was aimed at ensuring high content validity of our questionnaires (Rubio et al., 2003). Thereafter, we distributed the questionnaires to the target population.

\subsection{Participants and criteria for data collection}

We collected data from foreign nationals currently working in companies located in different cities in China such as Beijing, Hefei, Shanghai, and so on. We categorized the respondents according to gender, education level, ethnicity/race and age. We explained the objective of the study to the respondents before requesting their participation in the survey. A self-administered survey technique was employed in this study, whereby a URL survey link was sent to potential respondents through email and a smartphone app (WeChat). For data collection, snowball sampling technique was used for distribution of survey. In order to ensure a higher response rate from the target population, we requested the respondents share the survey link in their chat rooms and groups, during the months of November, 2018 to January, 2019. For instance, expatriates from African countries residing in cities across China have WeChat groups in which they share information amongst each other. Through this self-administered survey, 420 questionnaires were filled out, 366 questionnaires were found to be eligible for this research. This gave a response rate of $87 \%$, which is acceptable for analysis (Kelley, Clark, Brown, \& Sitzia, 2003). Table 1 shows demographic of respondents in the form of frequency and percentage. For this survey, $192(52.5 \%)$ respondents were male and $174(47.5 \%)$ were female which includes 121 black (33.1\%), 188 (51.4\%) and $57(15.5 \%)$ Arab. Age wis distribution shows that high number of participants were between 31 to 35 years i.e., 179 (48.9\%), and $168(45.9 \%)$ were between 25 to 30 years of age, $18(4.9 \%)$ participants were 
above 35 years, and remaining participants were between 18 to 24 years. The demographic features of the respondents are presented in Table 1.

Table 1. Demographics of respondents

\begin{tabular}{lccc}
\hline Demographics & & Frequency & Percentage (\%) \\
\hline Gender & Male & 192 & 52.5 \\
\hline Ethnicity & Female & 174 & 47.5 \\
\hline & Black & 121 & 33.1 \\
\hline & Asian & 188 & 51.4 \\
\hline Education level & Bachelor's degree & 57 & 15.5 \\
\hline & Master's degree & 244 & 1.1 \\
\hline & PhD degree & 118 & 66.7 \\
\hline Age & 18 to 24 years & 1 & 32.2 \\
\hline & 25 to 30 years & 168 & 0.3 \\
\hline & 31 to 35 years & 179 & 45.9 \\
\hline & Above 35 years & 18 & 48.9 \\
\hline
\end{tabular}

Source: own calculation

\subsection{Measurement of constructs}

The measurement items used were both adopted and adapted from previous studies, with small amendments in wording to suit the current study. Ten items for perceived prejudice were adapted from Molero, Recio, García-Ael, Fuster, and Sanjuán (2013). Five items were trust in government from Gefen, Karahanna, and Straub (2003); self-esteem from Rosenberg (1965). We adapted six items expatriates' affective commitment from Meyer, Allen, and Smith (1993). For turnover intention variable, we adapted five items from the work of Allen, Shore, and Griffeth (2003).

\subsection{Statistical analysis}

Structural Equation Modelling (SEM) was used in this study to measure and analyze our research model, whereby both the measurement and structural models were examined. SEM was selected due its increase in popularity across many disciplines (Lomax \& Schumacker, 2004). To begin with, we performed an Explanatory Factor Analysis (EFA) using IBM SPSS 23 , in which we extracted variables from the measurement items by the maximum likelihood method and rotated by Promax. For the Confirmatory Factor Analysis (CFA), we utilized Lisrel software, an instrument which uses regression and CFA simultaneously in estimating measurement and structural models. Lastly, we applied hierarchical regression to investigate the moderation effects on independent and dependent variables. For this we used Microsoft Windows operating system-based IBM SPSS 23 statistical software application.

\section{Results}

\subsection{Internal consistency and validity}

To test the internal consistency of our measurement items, we generated the Cronbach's $\alpha$ values for each construct as suggested in previous empirical studies (Gliem \& Gliem, 2003). An $\alpha \geq 0.9$ is normally considered as an excellent, and $0.7 \leq \alpha<0.9$ is considered good internal 
consistency. A liability test was run to examine the validity of the data. Previous research has established that, when latent variables are used in an empirical study, the Cronbach's $\alpha$, Composite Reliability (CR) and Average Variance Extracted (AVE) of each variable are essential indices for testing validity of the data. The threshold values for each are 0.7, 0.7 and 0.5 , respectively (Sunguh, Abbas, Olabode, \& Xuehe, 2019). The set of values generated for the variables used in this study are presented in Table 2. As shown, the values for Cronbach's $\alpha, \mathrm{AVE}$ and $\mathrm{CR}$ are greater than the threshold values, indicating that the extracted constructs have good internal consistency and are reliable.

Table 2. Result of Factor loading, Cronbach's alpha, Composite Reliability (CR), and Average Variance Extracted (AVE)

\begin{tabular}{|c|c|c|c|c|}
\hline Constructs & Factor loading & Cronbach's alpha & $\mathrm{CR}$ & AVE \\
\hline \multirow[t]{11}{*}{ Perceived prejudice } & & .977 & .965 & .558 \\
\hline & PP1 & .906 & & \\
\hline & PP2 & .897 & & \\
\hline & PP3 & .891 & & \\
\hline & PP4 & .896 & & \\
\hline & PP5 & .893 & & \\
\hline & PP6 & .892 & & \\
\hline & PP7 & .882 & & \\
\hline & PP8 & .872 & & \\
\hline & PP9 & .893 & & \\
\hline & PP10 & .921 & & \\
\hline \multirow[t]{11}{*}{ Self-esteem } & & .987 & .976 & .599 \\
\hline & SE1 & .977 & & \\
\hline & SE2 & .955 & & \\
\hline & SE3 & .944 & & \\
\hline & SE4 & .976 & & \\
\hline & SE5 & .889 & & \\
\hline & SE6 & .913 & & \\
\hline & SE7 & .943 & & \\
\hline & SE8 & .918 & & \\
\hline & SE9 & .926 & & \\
\hline & SE10 & .908 & & \\
\hline \multirow[t]{7}{*}{ Job commitment } & & .991 & .989 & .936 \\
\hline & $\mathrm{JC} 1$ & .997 & & \\
\hline & $\mathrm{JC} 2$ & .982 & & \\
\hline & $\mathrm{JC} 3$ & .957 & & \\
\hline & $\mathrm{JC} 4$ & .934 & & \\
\hline & JC5 & .940 & & \\
\hline & JC6 & .993 & & \\
\hline \multirow[t]{6}{*}{ Turnover intention } & & .975 & .963 & .838 \\
\hline & TI1 & .879 & & \\
\hline & TI2 & .896 & & \\
\hline & TI3 & .927 & & \\
\hline & TI4 & .973 & & \\
\hline & TI5 & .900 & & \\
\hline \multirow[t]{2}{*}{ Trust in host government } & & .993 & .988 & .923 \\
\hline & TG1 & .991 & & \\
\hline
\end{tabular}




\begin{aligned} \hline TG2 & .921 \\ \hline TG3 & .940 \\ \hline TG4 & .958 \\ \hline TG5 & .968 \\ \hline TG6 & .958 \\ \hline TG7 & .988\end{aligned}

Extraction method, Maximum likelihood, Rotation method, Promax with Kasier Normalization Source: own calculation

There is also an alternative procedure to investigate discriminate validity, first presented in a study by Fornell and Larcker (1981). This is done by calculating the square root of the AVE values of each construct and then equating these with the correlation values between respective constructs. Thus, good discriminate validity of a construct would be indicated if the square root of AVE is greater than the respective correlation among the constructs. When the data was subjected to this method, the results indicated good discriminate validity, just as depicted by the first method. This can be seen in Table 3 .

Table 3. Descriptive statistics, Correlation matrix, Reliability, and Square root of AVE

\begin{tabular}{ccccccccc}
\hline Sr. & Constructs & M & SD & 1 & 2 & 3 & 4 & 5 \\
\hline 1. & $\begin{array}{c}\text { Perceived } \\
\text { prejudice }\end{array}$ & 2.40 & 1.07 & $\mathbf{0 . 7 4 7}$ & & & & \\
\hline 2. & Self-esteem & 1.86 & 0.89 & -.113 & $\mathbf{0 . 7 7 4}$ & & & \\
\hline 3. & $\begin{array}{c}\text { Job } \\
\text { commitment }\end{array}$ & 3.07 & 1.50 & -0.268 & 0.486 & $\mathbf{0 . 9 6 7}$ & & \\
\hline 4 & $\begin{array}{c}\text { Turnover } \\
\text { intention }\end{array}$ & 3.86 & 1.10 & 0.228 & 0.602 & $-0,554$ & $\mathbf{0 . 9 1 6}$ & \\
\hline 5. & $\begin{array}{c}\text { Trust in host } \\
\text { government }\end{array}$ & 3.36 & 1.51 & -0.590 & 0.291 & 0.364 & -0.363 & $\mathbf{0 . 9 6 1}$ \\
\hline
\end{tabular}

$M-$ Mean; $S D-$ Standard deviation.

Note: $N=373$. All correlations are significant at $p<0.001$.

Bold values on the diagonal represent square root of average variance extracted (AVE).

Source: own calculation

\subsection{Confirmatory Factor Analysis (CFA)}

The main purpose for conducting a CFA is to evaluate the goodness of fit of the proposed models, which is done by comparing the generated indices against the threshold values. For such an evaluation, the most popular index values required are the goodness of fit index (GFI), adjusted goodness of fit index (AGFI), Tucker-Lewis's index (TLI), comparative fit index (CFI) and root mean square root error of approximation (RMSEA) (Zulfiqar, Sarwar, Aziz, Ejaz Chandia, \& Khan, 2018). Research has established the threshold values for each of the parameters. In regard to RMSEA, models with values $<0.05$ are considered as perfect fits, between 0.05 and 0.08 are good fits, while values $>0.08$ are regarded as poor fits. Based on this criterion, both our measurement and structural models can be termed good fits. Furthermore, previous studies have suggested that the ratio between the chi-square value and the degree of freedom should be less than 3.0, and in this case our models' goodness of fit can be said to be acceptable (Levine, 2005).

GFI and AGFI values depend on the sample size used in the study. According to a study by Kurfalı, Arifoğlu, Tokdemir, and Paçin (2017), a value of $>0.90$ is preferred, but due to sensitivity to sample size, a value $>0.80$ is also acceptable for a good fit. In addition, they 
recommend that NFI, CFI and IFI values of > 0.80 represent a good and acceptable measurement and structural models. We employed SEM in this research and generated the values for the aforementioned goodness of fit indices. The values generated are within the acceptable threshold values, and this therefore indicated an acceptable and suitable goodnessof-fit for both the measurement and structural models. Table 4 and Table 5 presents the SEM data generated in this study for both the measurement model and structural model. In each case, the goodness fit index values are compared against the threshold values as established in previous studies.

Table 4. Goodness of fit statistics for measurement model

\begin{tabular}{lccccccccc}
\hline Model & $\mathrm{X}^{2}$ & $\mathrm{df}$ & $\mathrm{X}^{2} / \mathrm{df}$ & GFI & AGFI & RMSEA & CFI & IFI & NFI \\
\hline Range & - & - & $<3.00$ & $>0.8$ & $>0.80$ & $<0.08$ & $>0.9$ & $>0.9$ & $>0.9$ \\
\hline Base & 1130.70 & 655 & 1.726 & 0.86 & 0.84 & 0.045 & 0.99 & 0.99 & 0.98 \\
\hline
\end{tabular}

Source: own calculation

Table 5. Goodness of fit statistics for structural model

\begin{tabular}{lccccccccc}
\hline Model & $\mathrm{X}^{2}$ & $\mathrm{df}$ & $\mathrm{X}^{2} / \mathrm{df}$ & GFI & AGFI & RMSEA & CFI & IFI & NFI \\
\hline Range & - & - & $<3.00$ & $>0.8$ & $>0.80$ & $<0.08$ & $>0.9$ & $>0.9$ & $>0.9$ \\
\hline Base & 1397.08 & 661 & 2.114 & 0.83 & 0.81 & 0.055 & 0.99 & 0.99 & 0.98 \\
\hline
\end{tabular}

Source: own calculation

\subsection{Hypothesis testing and its effects}

After the data analysis, the results depict that perceived prejudice significantly negatively impacted trust in the host government $(\beta 1=-0.61, \mathrm{p}<0.001)$. In addition, perceived prejudice negatively impacted expatriates' affective job commitment and positively impacted expatriates' turnover intention. It was found, however, that when trust in host government was used as a mediator, the negative effects of prejudice on affective commitment were reduced and the positive effects on turnover intention significantly reduced. This indicated that trust in host government partially mediated the relationship between perceived prejudice and expatriates' affective job commitment and fully mediated the relationship between perceived prejudice and turnover intention. Trust in host government was found to be positively associated with expatriates' affective commitment $(\beta 1=-0.37, \mathrm{p}<0.001)$ and negatively related to expatriates' turnover intention $(\beta 1=-0.37, \mathrm{p}<0.001)$. The two relations were found to be highly significant, indicating the role trust in government plays in expatriates developing positive attitudes towards their jobs and remaining committed to their assignments.

These results therefore indicate that our hypotheses $H 1, H 2$ and $H 3$ are all supported. Specifically, after conducting SEM and hierarchical regression analysis, the results indicate support for our view that trust in the host government by low-status expatriates mediates the relationship between perceived prejudice and expatriates' work attitudes, namely affective job commitment and turnover intention. The path diagram in Figure 2 depicts the significant paths between the variables, showing the hypotheses are discussed earlier.

\subsubsection{Moderation effects of self-esteem}

We examined the role expatriates' self-esteem might play in moderating the relationship between trust in the host government and expatriates' critical decisions to remain committed to their jobs or repatriate before the end of their assignment. This study investigated the moderation effects using IBM SPSS 23 because it can carry out hierarchical regression, which 
allows researchers to examine the moderation effects of a variable on a relationship between an independent and a dependent variable (Bolin, 2014). The analysis indicated that race and gender were the only significant control variables.

Table 6. Moderation effects of self-esteem between trust in host government and job commitment

\begin{tabular}{ccccc}
\hline Constructs & M1 & M2 & M3 & M4 \\
\hline Trust in host government & & $.328 * * *$ & $.221^{* * *}$ & $-.253 *$ \\
\hline Self-esteem & & & $.419 * * *$ & .143 \\
\hline $\begin{array}{c}\text { Self-esteem x Trust in host } \\
\text { government }\end{array}$ & & & & $.850 * * *$ \\
\hline $\mathrm{F}$ & $9.484 * * *$ & $13.848^{* * *}$ & $28.216^{* * *}$ & $30.310^{* * *}$ \\
\hline$\Delta \mathrm{R}^{2}$ & 0.085 & 0.150 & 0.309 & 0.360 \\
\hline
\end{tabular}

Note: $* * *-p<0.001, * *-p<0.01, *-p<0.05$

Source: own calculation

Table 7. Moderation effects of self-esteem between trust in host government and turnover intention

\begin{tabular}{ccccc}
\hline Constructs & $\mathrm{M} 1$ & $\mathrm{M} 2$ & $\mathrm{M} 3$ & $\mathrm{M} 4$ \\
\hline Trust in host government & & $-.351 * * *$ & $-.208^{* * *}$ & -.21 \\
\hline Self-esteem & & & $-.562 * * *$ & $-.340 * *$ \\
\hline $\begin{array}{c}\text { Self-esteem x Trust in host } \\
\text { government }\end{array}$ & & & & $-.335^{* * *}$ \\
\hline $\mathrm{F}$ & $5.785^{* * *}$ & $11.355^{* * *}$ & $43.798^{* * *}$ & $38.686^{* * *}$ \\
\hline$\Delta \mathrm{R}^{2}$ & 0.050 & 0.124 & 0.413 & 0.420 \\
\hline
\end{tabular}

Note: $* * *-p<0.001, * *-p<0.01, *-p<0.05$

Source: own calculation

a) Job commitment

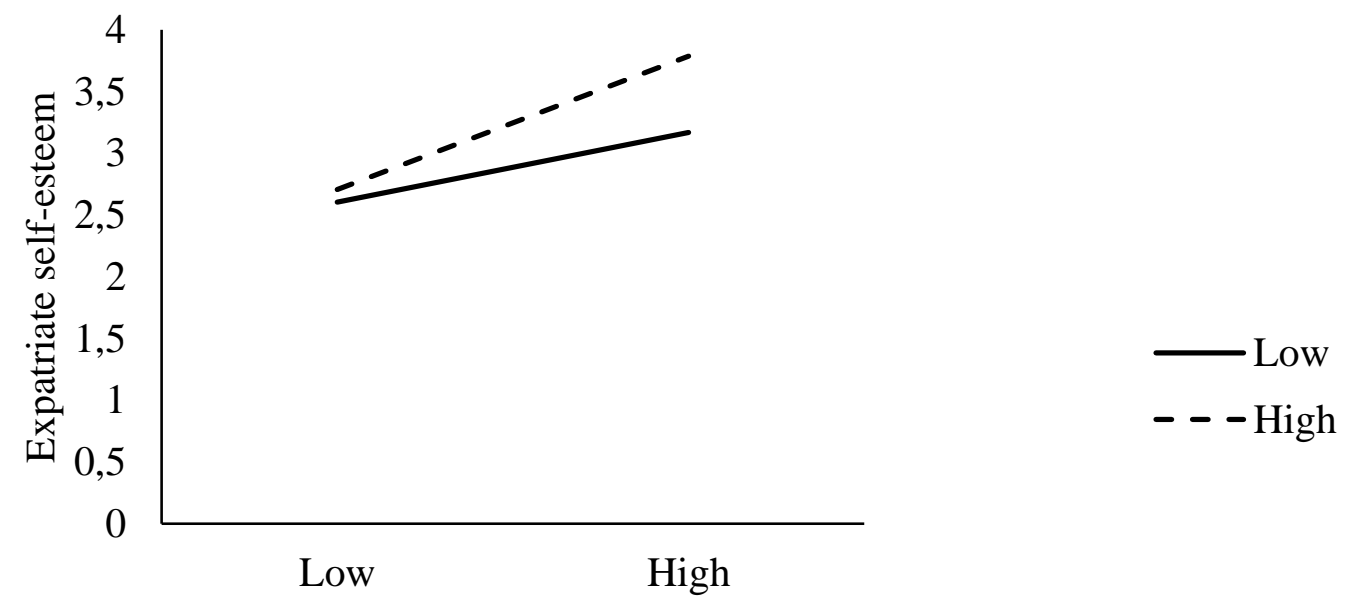

Trust in host government

Figure 3. Moderation effects between trust in host government and expatriate job commitment Source: own compilation 
b) Turnover intention

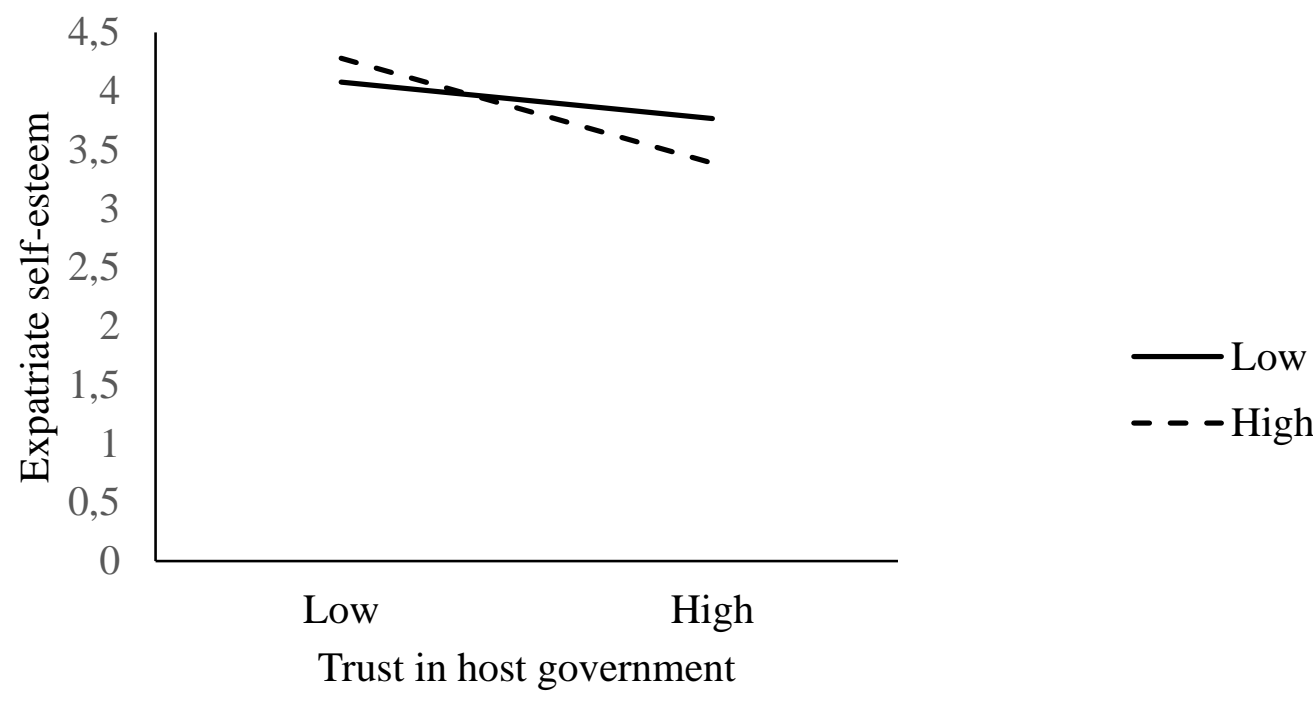

Figure 4. Moderation effects between trust in host government and expatriate turnover intention Source: own compilation

Our analysis depicted that by using trust in host government as an independent variable and both expatriates' affective commitment and turnover intention as dependent variables, the moderation effects of expatriates' self-esteem are significant in all of the relationships. In the Table 6, we found that self-esteem positively moderates the relationship between trust in host government and expatriates' job commitment $(\beta=0.850 \mathrm{p}<.001)$. As Table 7 illustrates, negatively moderates the relationship between trust in host government and expatriates' turnover intention $(\beta=-0.335 \mathrm{p}<.05)$. This affirms the contention that in the event prejudice is perceived by low-status expatriates, their trust in the host government combined with their individual self-esteem will mitigate the negative effects associated with the prejudice, acting as a cushion and allowing them to remain positive and committed. Consequently, Figure 3 demonstrates that expatriates who possess higher levels of self-esteem and confidence achieve higher levels of job commitment. Figure 4 present that expatriates who possess higher levels of self-esteem achieved less turnover intention, posting better results than their counterparts possessing low self-esteem levels. The results from the hierarchical regression, testing the selfesteem has moderation effects between trust and commitment and turnover intention respectively.

\section{Discussion}

The main intent of this research was to explore the effectiveness of expatriates' trust in host governments in mitigating the negative effects of perceived prejudice. It has established that general trust in the host government by expatriates has an impact on both their affective commitment and turnover intention, essential individual work attitudes that affect their work performance and success (Shaffer \& Harrison, 1998). With increases in globalization and knowledge economies, and limited resources in the developing world, there has been an influx in the number of employees from developing regions who are willing to relocate to other countries in search of job opportunities. The success of these individuals in their new assignments, as research has shown, depends on a variety of factors which can be social, 
economic and even political. Providing insight on how these expatriates overcome the many challenges they face during the tenure of their international assignments can help policy makers and other actors to address said challenges and hence improve. Our research also integrated social categorization theory to explain why host nationals would be expected to align themselves more with high-status expatriates than low-status and used social capital theory to address the aspect of trust. Low-status expatriates develop a relationship with host government entities by trusting them to come through in the event they are needed.

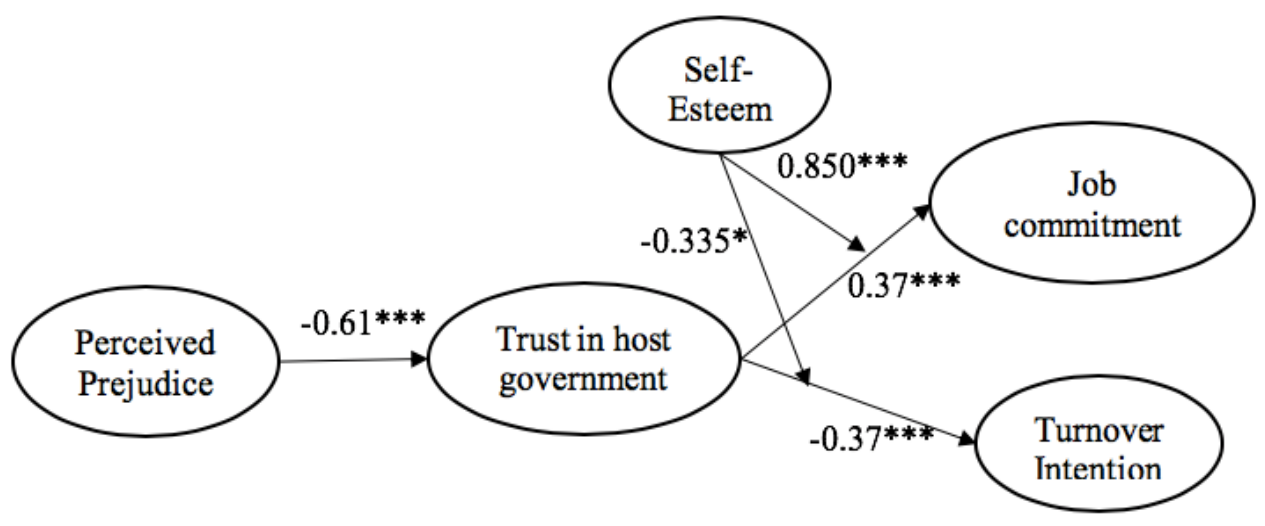

Figure 2. Path diagram

Source: own compilation

As shown in the path diagram in Figure 2, low-status expatriates' currently living in China trust in the host government is an essential factor in the success of their international assignments. Therefore, factors that would diminish this trusting attitude should be a focus of host firms and governments if they desire to attract and retain expatriates. The results confirm that perceived prejudice is significantly and negatively associated with low-status expatriates' feelings of trust and commitment to their work and is positively related to their intention to quit (Shields \& Price, 2002).

Furthermore, the findings show that expatriates' general trust in the host government can mitigate the negative effects from perceived prejudice, partially mediating the relationship between prejudice and expatriates' job commitment and fully mediating the relationship between prejudice and turnover intention. This research has also established the role of expatriates' self-esteem in moderating the relationship between trust in the host government and expatriates' work attitudes, specifically job commitment and turnover intention.

This study is among the first to investigate the effects that prejudice has on low-status expatriates' job success through social categorization theory. In this regard, it provides substantial contributions to the literature on global mobility and international human resources by using social categorization theory to explain the behavior of host nationals towards lowstatus expatriates and the effect it has on their jobs. Furthermore, the study shows how lowstatus expatriates' self-esteem enables them to achieve their career goals by assuming a moderating role that leads to higher job commitment and lower turnover intention (Lee \& Peccei, 2007). Nevertheless, the results suggested in this study should be consider with caution because the findings only reported the emotions and point of view of expatriates living in different cities of China. In other to further understand the emotions and point of view of low- 
status expatriates, more research is needed, especially considering expatriates living in different cultural environments (i.e., developed, developing or least developed countries).

\section{Conclusion}

This research has established that low-status expatriates in China tend to rely on the host government and their self-esteem to assist them in developing positive job attitudes. It implies that in the presence of unfavorable working conditions such as prejudice, low-status expatriates consider their trust in the host government in deciding whether to stay committed to their jobs. In this situation they also use self-cognitions such as self-esteem to compensate for the lack of or reduced support from host nationals to stay committed.

This is an interesting finding, since most previous studies emphasized selection of qualified personnel, pre-training before posting and organizational support as major factors contributing to success. They expected that expatriates would stay committed and successfully complete their assignments provided that they were provided with training and given support by the organization and host nationals, among other aspects. However, this line of reasoning disregards that expatriates perceived to be of low status face challenges in host national support and from prejudice, possibly resulting in psychological suffering. These are challenges for which it is difficult to prepare. Fundamental propositions in the global mobility and expatriate management field include (1) an increase in expatriates' job commitment, and therefore a reduction in their turnover intention, is essential for the success of their assignments, and (2) psychological and emotional welfare at work contributes positively to expatriates' job commitment and negatively affects their intention to quit. Based on these propositions, it is apparent that low-status expatriates can realize positive work attitudes only to the extent that they are able to compensate for the lack of important support from host nationals and to address the psychological suffering, fear and uncertainty resulting from experiences or perceptions of prejudice.

Developing and nurturing relationships with the host government is a potential mechanism to counter the fear and uncertainty, since they would provide a sense of emotional and psychological security to cushion against unfavorable experiences. Furthermore, this study has shown that developing self-cognitions, in this case self-esteem, would enable expatriates to be self-reliant and adaptable to new realities, consequently remaining committed to their jobs. Expatriates possessing higher levels of self-esteem are expected to be more committed to their assignments. This observation stresses the crucial role the personal characteristics of expatriates play in their adaptability and job success. Self-esteem is also shown to significantly moderate the relationship between trust in host government and work attitudes. This demonstrates that the burden to manage expatriate success rests not only on the expatriates themselves and the firms they are attached to but also on the host government. Governments and their agents should engage actors involved in international human resources to develop policies that would create friendly and trustworthy environments perceived to be just and of high integrity. This would help in attracting high-skilled expatriates from both low- and high-status countries.

Finally, social categorization theory provides a meaningful theoretical lens to understand the behavior of host nationals towards low-status expatriates and can be further developed with regard to the adaptability of low-status expatriates. This study has established that there is a need to be specific when tackling challenges faced by expatriates because different subgroups face unique challenges (Jokinen, Brewster, \& Suutari, 2008; Toh \& DeNisi, 2005). We posit that developing theoretical approaches that suit different types of expatriates would be helpful in addressing their challenges. This study has attempted to address the challenges faced by low-status expatriates living in China by providing strong empirical evidence of status-based prejudice. This leads host nationals to be biased in terms of support 
and can sometimes lead to harmful and regrettable occurrences like xenophobic attacks (AlAdwani, 2018; Pauw, Collins, \& Gouws, 2017). Thus, any challenges that may arise for this type of expatriates would be best addressed using the assumptions and assertions developed by social categorization theory.

\section{Acknowledgements}

The authors would like to acknowledge the technical and financial support of Writing Lab, Institute for the Future of Education, Tecnologico de Monterrey, Mexico, in the production of this work.

\section{References}

Abbas, A., Fatima, A., Sunguh, K.K., Avdic, A. \& Zhang, X. (2018). Digital rights management in China: Challenges and opportunities. Journal of Cases on Information Technology, 20(1), 20-30.

Al-Adwani, S. (2018). Xenophobia: Expats and Immigrants. AUK Repository.

Allen, D. G., Shore, L. M., \& Griffeth, R. W. (2003). The role of perceived organizational support and supportive human resource practices in the turnover process. Journal of Management, 29(1), 99-118.

Ar A.Y. (2021) Corporate Social Responsibility. Harris P., Bitonti A., Fleisher C.S., Skorkjær Binderkrantz A. (eds) The Palgrave Encyclopedia of Interest Groups, Lobbying and Public Affairs. Palgrave Macmillan, Cham.

Aycan, Z. (1997). Expatriate adjustment as a multifaceted phenomenon: Individual and organizational level predictors. International Journal of Human Resource Management, $8(4), 434-456$.

Bolin, J. H. (2014). Introduction to Mediation, Moderation, and Conditional Process Analysis: A Regression-Based Approach by Andrew F. Hayes. Journal of Educational Measurement, 51(3), 335-337.

Bonache, J., Langinier, H., \& Zárraga-Oberty, C. (2016). Antecedents and effects of host country nationals negative stereotyping of corporate expatriates. A social identity analysis. Human Resource Management Review, 26(1), 59-68.

Borgatti, S. P., Jones, C., \& Everett, M. G. (1998). Network measures of social capital. Connections, 21(2), 27-36.

Caligiuri, P. M. (2000). Selecting expatriates for personality characteristics: A moderating effect of personality on the relationship between host national contact and cross-cultural adjustment. MIR: Management International Review, 61-80.

Cuddy, A. J., Norton, M. I., \& Fiske, S. T. (2005). This old stereotype: The pervasiveness and persistence of the elderly stereotype. Journal of Social Issues, 61(2), 267-285.

de Eccher, U., \& Duarte, H. (2018). How images about emerging economies influence the willingness to accept expatriate assignments. The International Journal of Human Resource Management, 29(4), 637-663.

Dovidio, J. F., Gaertner, S. L., \& Validzic, A. (1998). Intergroup bias: Status, differentiation, and a common in-group identity. Journal of Personality and Social Psychology, 75(1), 109-120.

Ellemers, N., Kortekaas, P., \& Ouwerkerk, J. W. (1999). Self-categorisation, commitment to the group and group self-esteem as related but distinct aspects of social identity. European Journal of Social Psychology, 29(2-3), 371-389. 
Ensher, E. A., Grant-Vallone, E. J., \& Donaldson, S. I. (2001). Effects of perceived discrimination on job satisfaction, organizational commitment, organizational citizenship behavior, and grievances. Human Resource Development Quarterly, 12(1), 53-72.

Faeth, P. C., \& Kittler, M. G. (2017). How do you fear? Examining expatriates' perception of danger and its consequences. Journal of Global Mobility, 5(4), 391-417.

Fechter, A.-M., \& Walsh, K. (2010). Examining 'expatriate' continuities: Postcolonial approaches to mobile professionals. Journal of Ethnic and Migration Studies, 36(8), 1197-1210.

Feldman, D. C., \& Tompson, H. B. (1993). Expatriation, repatriation, and domestic geographical relocation: An empirical investigation of adjustment to new job assignments. Journal of International Business Studies, 24(3), 507-529.

Florkowski, G. W., \& Fogel, D. S. (1999). Expatriate adjustment and commitment: The role of host-unit treatment. International Journal of Human Resource Management, 10(5), 783-807.

Fornell, C., \& Larcker, D. F. (1981). Evaluating structural equation models with unobservable variables and measurement error. Journal of Marketing Research, 39-50.

Gefen, D., Karahanna, E., \& Straub, D. W. (2003). Trust and TAM in online shopping: An integrated model. MIS Quarterly, 27(1), 51-90.

Gliem, J. A., \& Gliem, R. R. (2003). Calculating, interpreting, and reporting Cronbach's alpha reliability coefficient for Likert-type scales. In Proceedings of the 2003 Midwest Research to Practice Conference in Adult, Continuing and Community Education, Ohio, State University, Columbus, Ohio.

Guttormsen, D.S., \& Francesco, A.M. (2019). Do lower status expatriates in multinational corporations experience different types of success? Journal of Global Mobility, 7(4), 364-380.

Haak-Saheem, W., Festing, M., \& Darwish, T. K. (2017). International human resource management in the Arab Gulf States-an institutional perspective. The International Journal of Human Resource Management, 28(18), 2684-2712.

Harcourt, J. (2013). Sexual identity distress, social support, and the health of gay, lesbian, and bisexual youth. Current Issues in Lesbian, Gay, Bisexual, and Transgender Health, 97126.

Hutchings, K. (2003). Cross-cultural preparation of Australian expatriates in organisations in China: The need for greater attention to training. Asia Pacific Journal of Management, 20(3), 375-396.

Ipek, E., \& Paulus, P. (2021). The influence of personality on individuals' expatriation willingness in the context of safe and dangerous environment. Journal of Global Mobility, 9(2), 264-288.

Jannesari, M. T., \& Sullivan, S. E. (2021). How relationship quality, autonomous work motivation and socialization experience influence the adjustment of self-initiated expatriates in China. Cross Cultural \& Strategic Management, 28(2), 309-331.

Johanson, G. A., \& Brooks, G. P. (2010). Initial scale development: Sample size for pilot studies. Educational and Psychological Measurement, 70(3), 394-400.

Jokinen, T., Brewster, C., \& Suustari, V. (2008). Career capital during international work experiences: Contrasting self-initiated expatriates experiences and assigned expatriation. The International Journal of Human Resource Management, 19(6), 979998.

Jureidini, R. (2005). Migrant workers and xenophobia in the Middle East. Racism and Public Policy, 48-71. 
Kim, J., \& Froese, F. J. (2012). Expatriation willingness in Asia: the importance of host-country characteristics and employees' role commitments. The International Journal of Human Resource Management, 23(16), 3414-3433.

Ko, J., \& Hur, S. (2014). The impacts of employee benefits, procedural justice, and managerial trustworthiness on work attitudes: Integrated understanding based on social exchange theory. Public Administration Review, 74(2), 176-187.

Kurfalı, M., Arifoğlu, A., Tokdemir, G., \& Paçin, Y. (2017). Adoption of e-government services in Turkey. Computers in Human Behavior, 66, 168-178.

Lee, J., \& Peccei, R. (2007). Perceived organizational support and affective commitment: the mediating role of organization-based self-esteem in the context of job insecurity. Journal of Organizational Behavior, 28(6), 661-685.

Levine, T. R. (2005). Confirmatory factor analysis and scale validation in communication research. Communication Research Reports, 22(4), 335-338.

Schumacker, R. E., \& Lomax, R. G. (2004). A beginner's guide to structural equation modeling. Psychology Press.

Lueke, S. B., \& Svyantek, D. J. (2000). Organizational socialization in the host country: The missing link in reducing expatriate turnover. The International Journal of Organizational Analysis, 8(4), 380-400.

Luhtanen, R., \& Crocker, J. (1992). A collective self-esteem scale: Self-evaluation of one's social identity. Personality and Social Psychology Bulletin, 18(3), 302-318.

Madera, J. M., King, E. B., \& Hebl, M. R. (2012). Bringing social identity to work: The influence of manifestation and suppression on perceived discrimination, job satisfaction, and turnover intentions. Cultural Diversity and Ethnic Minority Psychology, 18(2), 165.

Mäkelä, K. (2007). Knowledge sharing through expatriate relationships: A social capital perspective. International Studies of Management \& Organization, 37(3), 108-125.

McNulty, Y., \& Brewster, C. (2017). Theorizing the meaning(s) of expatriate: establishing boundary conditions for business expatriates. The International Journal of Human Resource Management, 28(1), 27-61.

McPhail, R., McNulty, Y., \& Hutchings, K. (2016). Lesbian and gay expatriation: Opportunities, barriers and challenges for global mobility. The International Journal of Human Resource Management, 27(3), 382-406.

Meyer, J. P., Allen, N. J., \& Smith, C. A. (1993). Commitment to organizations and occupations: Extension and test of a three-component conceptualization. Journal of Applied Psychology, 78(4), 538.

Minter, R. L. (2008). Preparation of expatriates for global assignments: Revisited. Journal of Diversity Management-Second Quarter, 3(2), 37-42.

Molero, F., Recio, P., García-Ael, C., Fuster, M. J., \& Sanjuán, P. (2013). Measuring dimensions of perceived discrimination in five stigmatized groups. Social Indicators Research, 114(3), 901-914.

Osland, G., \& Björkman, I. (1998). MNC-host government interaction: Government pressures on MNCS in China. European Management Journal, 16(1), 91-100.

Pauw, H., Collins, C., \& Gouws, S. (2017). African Migrants and European Expatriates in Port Elizabeth, South Africa. Diversity and Local Contexts, 167-189.

Pinnington, A. (2011). Strategic Management and IHRM. In Hazing, A. \& Pinnington, A.H. (eds). International Human Resource Management, Sage Publications.

Riketta, M. (2002). Attitudinal organizational commitment and job performance: A metaanalysis. Journal of Organizational Behavior, 23(3), 257-266.

Rosenberg, M. (1965). Rosenberg self-esteem scale (RSE). Acceptance and commitment therapy. Measures package, 61. 
Rosenbusch, K., \& Cseh, M. (2012). The cross-cultural adjustment process of expatriate families in a multinational organization: A family system theory perspective. Human Resource Development International, 15(1), 61-77.

Rubio, D. M., Berg-Weger, M., Tebb, S. S., Lee, E. S., \& Rauch, S. (2003). Objectifying content validity: Conducting a content validity study in social work research. Social Work Research, 27(2), 94-104.

Shaffer, M. A., \& Harrison, D. A. (1998). Expatriates' psychological withdrawal from international assignments: Work, nonwork, and family influences. Personnel Psychology, 51(1), 87-118.

Shields, M. A., \& Price, S. W. (2002). Racial harassment, job satisfaction and intentions to quit: evidence from the British nursing profession. Economica, 69(274), 295-326.

Sinwell, L. (2011). Obtaining 'Peace', searching for justice: evaluating civil society and local government responses to xenophobia in Alexandra. Politikon, 38(1), 131-148.

Sunguh, K. K., Abbas, A., Olabode, A. C., \& Xuehe, Z. (2019). Do identity and status matter? A social identity theory perspective on the adaptability of low-status expatriates. Journal of Public Affairs, 19(4), e1938.

Terry, D. J., Pelly, R. N., Lalonde, R. N., \& Smith, J. R. (2006). Predictors of cultural adjustment: Intergroup status relations and boundary permeability. Group Processes \& Intergroup Relations, 9(2), 249-264.

Toh, S. M., \& DeNisi, A. S. (2005). A local perspective to expatriate success. Academy of Management Perspectives, 19(1), 132-146.

Toh, S. M., \& DeNisi, A. S. (2007). Host country nationals as socializing agents: A social identity approach. Journal of Organizational Behavior, 28(3), 281-301.

Toh, S. M., \& Srinivas, E. S. (2012). Perceptions of task cohesiveness and organizational support increase trust and information sharing between host country nationals and expatriate coworkers in Oman. Journal of World Business, 47(4), 696-705.

Varma, A., Budhwar, P., \& Pichler, S. (2011). Chinese host country nationals' willingness to help expatriates: The role of social categorization. Thunderbird International Business Review, 53(3), 353-364.

Varma, A., Toh, S. M., \& Budhwar, P. (2006). A new perspective on the female expatriate experience: The role of host country national categorization. Journal of World Business, 41(2), 112-120.

Zulfiqar, S., Sarwar, B., Aziz, S., Ejaz Chandia, K., \& Khan, M. K. (2018). An analysis of influence of business simulation games on business school students' attitude and intention toward entrepreneurial activities. Journal of Educational Computing Research, 0735633117746746. 